\title{
Policy Failure and Corruption in Belgium: Is Federalism to Blame?
}

\author{
JEROEN MAESSCHALCK and STEVEN VAN DE WALLE
}

Throughout the 1990s, corruption cases, policy failure and scandals tarnished Belgium's international reputation. In this article, we analyse the effect of federalism and political culture on corruption and policy failures and their impact on the likelihood of such occurrences becoming scandals. Survey material suggests that there are few differences between French-and Dutch-speakers in the perception and tolerance of corruption. We then list a number of variables that can explain corruption in Belgium and argue that the independent effect of federalism is very limited. Next we demonstrate that federalism has played a much more significant role in lowering the risk of policy failure, while at the same time creating a few new vulnerabilities. Finally, we argue that the regional political elites do not often engage in policy learning and frequently put forward federalism as the main solution to the avoidance of policy failure and scandal. In this sense, regional political elites do not seize the opportunity for policy experimentation and transfer that is generally seen as one of the main virtues of a federal system of government.

Belgian politics seemed to have become synonymous with corruption, scandal and policy failure in the 1990s (Maesschalck 2002). The murder of socialist politician André Cools in 1991 marked the start of a scandal-ridden decade. The investigation into his killing led to the discovery of the AgustaDassault corruption scandal over bribes that had been paid in the procurement of helicopters for the military. The scandal caused the indictment of several politicians and forced the resignation of NATO Secretary-General and former Belgian Vice-Prime Minister Willy Claes. The Dutroux scandal in the mid-1990s had an even greater impact on the country's national mood and international image. The perceived incompetence of the police and the judiciary in dealing with a major paedophilia and child murder case led to massive popular outrage, reaching a peak in the 'White March' in Brussels: the largest protest march in Belgian post-war history. In 1999, it appeared that the administration had been unable to detect or prevent contamination of poultry, leading to the so-called dioxin scandal. Since the scandal emerged just before the elections, it contributed to a historic shift in the ruling 
coalition, with the Christian Democrats moving to the opposition benches for the first time in decades. These are just a few illustrations of the size and the impact of scandals in 1990s Belgium.

In this article we distinguish between corruption, policy failure (or fiasco) and scandal. Friedrich defines the first as 'deviant behaviour associated with a particular motivation, namely that of private gain at public expense' (Friedrich 1989: 15). As we emphasise political corruption, we will particularly focus on such deviant behaviour that implicates public officials. Compared with corruption, policy failure is a much broader concept, since it can mean 'a negative event that is perceived by a socially and politically significant group of people in the community to be at least partially caused by avoidable and blameworthy failures of public policymakers' (Bovens and 't Hart 1996). As such, policy failures can occur without malicious intent. In the examples listed above, the Agusta-Dassault bribes exemplify corruption; the failures in the Dutroux investigation illustrate a policy failure or fiasco. Finally, we consider scandal as a social and political construction that might be triggered by policy failure or fiasco. Many problems are not followed by scandal (Thompson 2000) and sometimes scandals are triggered by occurrences that, in other circumstances, would hardly be seen as problematic.

Seeking to provide a thorough explanation of the occurrence of corruption, policy failure and scandal in 1990s Belgium would be inappropriately ambitious within the scope of the present article. Of all three occurrences, this article will focus particularly on corruption. Furthermore, we will mainly emphasise the explanatory value of two variables. The first variable considers to what extent the (perception) of corruption is related to the coexistence of two different political cultures (Flemish and Walloon) in one state. Using survey data, we will analyse whether the Flemish are more prone to corrupt behaviour than the Walloons or vice versa. The second variable is the key variable linking the various contributions in this volume: federalism. Has the federalisation of Belgium, and, in particular, the peculiar structure which Belgian federalism acquired, affected the (perception) of corruption, policy failure and scandal? Or has Belgian federalism changed the institutions in such a way that they become more vulnerable to corruption, failure and scandal? (See Boin and 't Hart 2000 for the notion of 'institutional vulnerability'.)

\section{How Corrupt is Belgium?}

While qualitative analysis of the types of corruption occurring in Belgium has been made elsewhere (e.g. De Winter 2003; De Ruyver et al. 1999), we will focus on quantitative data. Between 1973 and 2003, De Winter (2003) counted about 100 important political corruption cases in Belgium. In 2003, 56.2 per cent of the Flemish agreed that you need 'connections' to get something done by government or the public administration, and just 13.4 per cent disagreed (Van de Walle 2007). Detailed empirical research on corruption in Belgium is scarce, however. In a European comparative 
perspective, perceptions of corruption in Belgium are quite high. In the 2005 Transparency International Corruption Perceptions Index Belgium was ranked 19th (http://www.transparency.org), above only Spain, Portugal and Italy out of the other Western European countries. 'Scandalitis' is a word that refers to an atmosphere of constant scandals, and was regularly used with reference to Belgian politics in the 1990s. But is Belgium's image of being a corrupt state correct, and why is corruption perceived to be higher in Belgium than in, say, Sweden?

Figure 1 shows the development in perceived corruption in Belgium. The right-hand vertical scale indicates the country's score on the Transparency International Corruption Perceptions Index, where 10 stands for low levels of perceived corruption. The left-hand scale shows answers from the Flemish administration's yearly surveys on social and cultural change (http://aps.vlaanderen.be). A representative sample of respondents in the Flemish Region $(\mathrm{n}=$ about 1,500$)$ had to pick from a list of 22 potential problems the five most important ones. In 1997, almost 40 per cent included (political) corruption in this list, while 6.5 per cent of respondents identified corruption as the most important problem. The figure suggests a change to lower levels of perceived corruption or at least a return to normalcy after a period of high perceived corruption.

Judicial statistics show a similar trend. Yante (2003) analysed judicial statistics before 1993, and found a clear decrease in the number of convictions for administrative corruption in the period between 1985 and 1992 as compared

FIGURE 1

PERCEIVED CORRUPTION IN BELGIUM-FLANDERS, 1996-2005

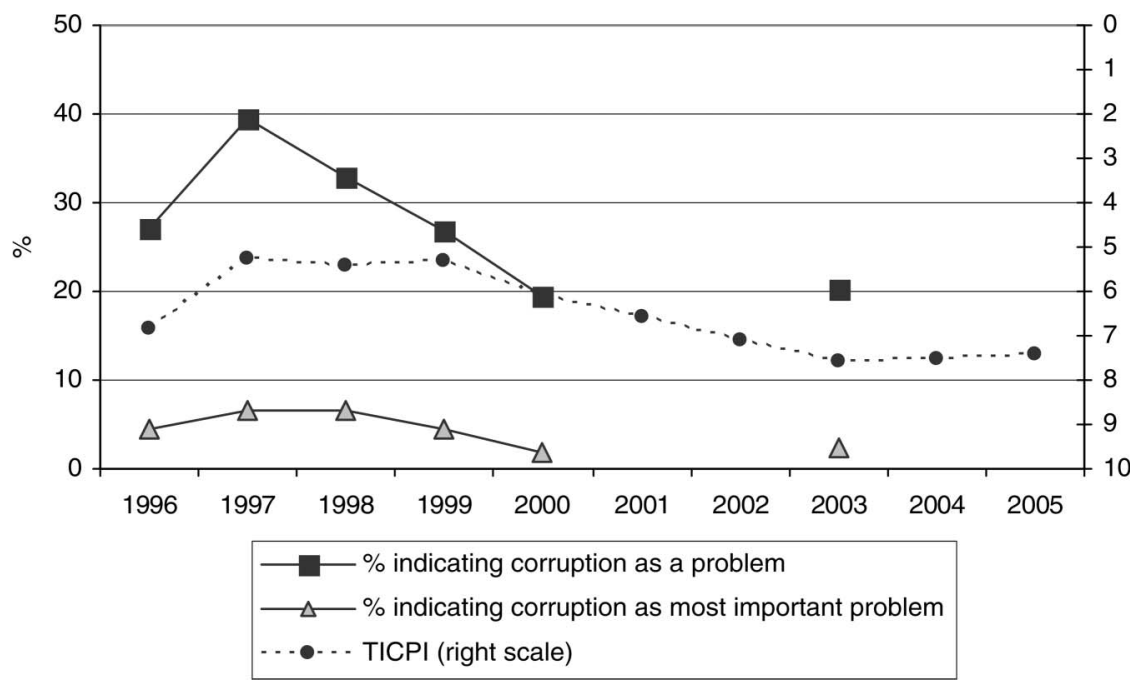

Source: Administratie Planning en Statistiek (http://aps.vlaanderen.be) and Transparency International (http:// www.transparency.org). 
to the preceding periods. At the same time, he observed a tendency towards more severe punishment, albeit many cases of active corruption only lead to a probationary sentence. More recent judicial statistics confirm this downward trend (Figure 2). Obviously, these statistics only refer to cases where corruption was actually discovered, reported, investigated and punished.

In the second round of the European Social Survey (ESS), 1,778 Belgians were interviewed on a broad range of issues (Jowell et al. 2005). The survey also included a number of items on corruption and bribery. Unsurprisingly, for reasons of social desirability, the number of respondents admitting to having offered a bribe to public officials is very low (just 14 people out of 1,770 over the past five years). However, the number of experiences with public officials asking for a bribe is equally low. A similar phenomenon has been reported with regard to experienced corruption in interactions with police officers (Van Kesteren et al. 2000). At the same time, however, the 2004 survey on social and cultural change in Flanders revealed that 17.5 per cent of Flemish citizens thought that many or almost everyone in the public administration was involved in corruption (Carton et al. 2005). Hence, there seems to be a difference between actual experience of corruption and the general image or perception.

The ESS surveys not only asked about actual occurrence of corruption, but also about attitudes. When asked how they evaluate a public official asking someone for a favour or bribe in return for their services, 94 per cent of Belgians answer that they consider this wrong. This percentage is similar

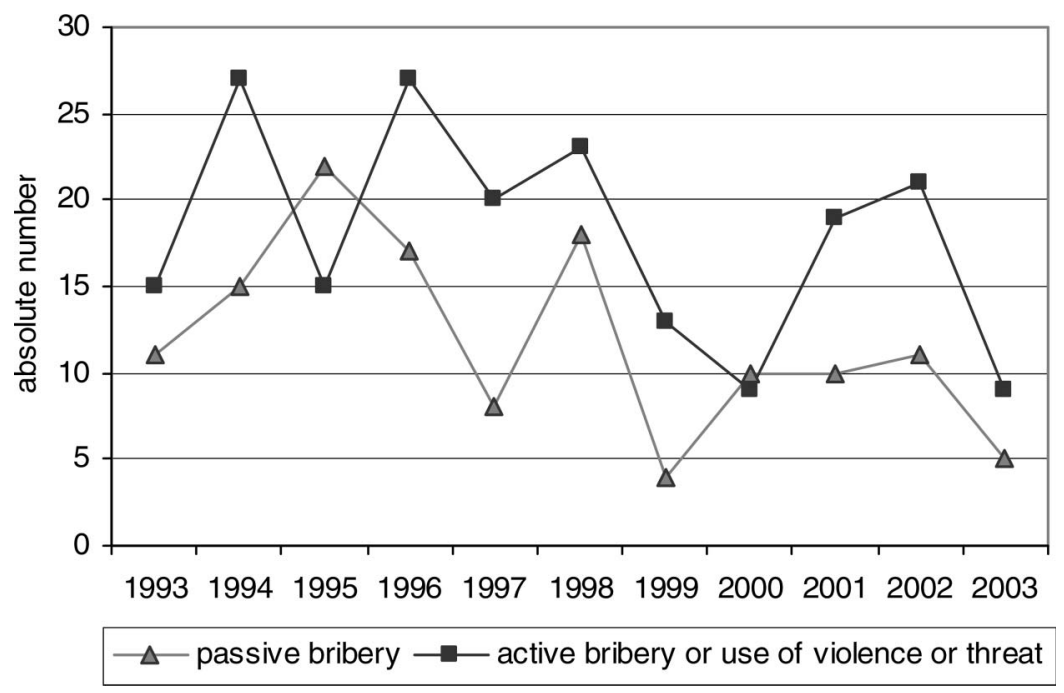

Source: FOD Justitie, Dienst Strafrechterlijk Beleid, Statistisch Steunpunt (http://www.dsb-spc.be). 
to that for the other countries which participated in the ESS. A similar question in the 1999-2000 European Values Survey did not reveal much between-country variation either. The ESS statement on whether you should always strictly obey the law even if this means missing good opportunities, however, showed the Belgians to be the most flexible of nations, with just 47 per cent agreeing. This is over 17 percentage points below the average for 17 European countries. This is quite interesting, especially when compared to the findings on attitudes to bribe-taking reported above. Yet there are variations in the attitudes towards corruption. The 1995 Belgian General Election Study revealed that Belgians have more problems with politicians asking for money for granting government contracts than with politicians who merely accept money. Also, corruption was considered worse when these politicians used the money for their personal election campaign as compared to when they gave it to their party (Beerten et al. 1997).

In sum, although survey evidence of attitudes towards, and occurrence of, corruption shows some differences with other European countries, there is no strong evidence that Belgium would be as dramatically corrupt as is sometimes suggested. The limited evidence available also suggests a downward trend since the late 1990s. When it comes to corruption perception, Belgium tends to score fairly low in a European perspective, but perceptionbased data should always be interpreted with great caution.

\section{Are there Regional Differences in Attitudes towards Corruption?}

Pujas and Rhodes (1999a: 689) wonder whether there is a clean north and a corrupt south in Europe, or whether there is a 'southern syndrome' (1999b: 41). They show how the Transparency International Corruption Perceptions Index suggests the existence of two groups of countries in Europe: a northern Protestant one and a southern Catholic one. Yet, they conclude, this does not explain why some countries have managed to eradicate corruption while others, geographically close, have not. They define Belgium as a northern country and have difficulties in explaining high levels of perceived corruption.

A more common argument, however, is that Belgium is on the border between the two groups, consisting of two separated administrative cultures (see also Brans et al. this volume): a southern one in French-speaking Wallonia, and a northern one in Dutch-speaking Flanders, although traces of a 'southern' culture are also said to be found in, until recently largely Catholic, Flanders. If this is the case, different approaches to corruption should be found in the two regions: high corruption and high acceptance in the south, and lower corruption and lower acceptance in the north.

\section{Differences in Perceived Corruption}

We first test whether corruption is perceived differently by Dutch- and French-speakers. We rely on data from the 1995 and 2003 Belgian General 
Election Studies, ${ }^{1}$ because of the large samples. The 1995 study contains several corruption-related issues, inspired by a series of corruption scandals in the first half of the 1990s. The 2003 survey contained a question on the perceived extent of bribe-taking among politicians. Rather than merely looking at the region in which respondents reside (Flanders, Wallonia, Brussels), we use the language in which the interview was conducted, precisely because we want to look at differences in political culture, which correspond more to linguistic than territorial lines. We first test differences in perceived corruption and then look at differences in public attitudes towards corruption.

When looking at the 1995 survey, French- and Dutch-speakers clearly differ in their perception of political corruption: French-speakers are more likely to state that politicians are more corrupt than other people (see Table 1). This difference remains significant when controlling for sex, age, education and income. Also in the 2003 survey, French-speakers perceive political corruption in Belgium to be considerably higher than Dutchspeakers (see Table 2). Language remains an important determinant of perceived corruption after controlling for sex, education, and age.

\section{Differences in Attitudes towards Corruption}

In the 1999 European Values Study (Inglehart et al. 2005), a question was included on the justifiability of accepting bribes in the course of one's duties. Two-thirds of the Belgians thought this could never be justified (one on a

TABLE 1

PERCEIVED CORRUPTION AMONG POLITICIANS IN BELGIUM, ACCORDING TO LANGUAGE OF RESPONDENT, 1995

\begin{tabular}{lrr}
\hline & French & Dutch \\
\hline Politicians more corrupt than other people & 41.5 & 30.2 \\
Politicians less corrupt than other people & 1.6 & 2.7 \\
Politicians not more or less corrupt than other people & 56.9 & 67.1 \\
\hline
\end{tabular}

Source: Belgian General Election Study 1995 (N=3,557), weighted for region, age and sex.

TABLE 2

PERCEIVED CORRUPTION AMONG POLITICIANS IN BELGIUM, ACCORDING TO LANGUAGE OF RESPONDENT, 2003

\begin{tabular}{lcc}
\hline $\begin{array}{l}\text { How widespread do you think corruption such as } \\
\text { bribe taking is among politicians in Belgium? }\end{array}$ & French & Dutch \\
\hline Very widespread & 50.4 & 24.5 \\
Quite widespread & 42.6 & 55.2 \\
Not very widespread & 3.1 & 15.4 \\
It hardly happens at all & 3.9 & 4.8 \\
\hline
\end{tabular}

Source: Belgian General Election Study $2003(\mathrm{~N}=2,225)$. 
one to ten scale), and only a small minority was tolerant towards accepting bribes. There is, however, a small but significant difference between Frenchand Dutch-speakers, with the French-speakers more often opting for the extreme option (75.6 per cent never justified), and the Dutch speakers more often found in categories 2-6 (62.1 per cent in category 1). In a multivariate analysis including socio-economic status, age, sex, education and the size of one's town, language remains the main determinant of attitudes towards bribes. We find a similar trend in the 1995 General Election Study: Frenchspeakers consider different types of political corruption (politicians accepting or asking money for government contracts, for personal use, or for party use) less acceptable than Dutch-speakers, again controlling for sociodemographics in a multivariate analysis (sex, age, education and income).

Finally, the 2005 European Social Survey also contained a number of items related to corrupt behaviour. Two of these were briefly discussed above: how respondents evaluate a public official asking someone for a bribe in return for their services, and what respondents think about the statement 'you should always strictly obey the law even if this means missing good opportunities'. Figures 3 and 4 disaggregate the responses for the three Regions. In the Flemish Region, 1,028 people were interviewed, in the Walloon Region 597 and in the Brussels Region 153.

Bivariate analysis shows differences between the three Regions in Belgium, with inhabitants of the Flemish Region being slightly more tolerant towards public officials asking for bribes. The Flemish were also less likely to agree that one should always strictly obey the law even if it

FIGURE 3

ATTITUDES TOWARDS OBEYING THE LAW: YOU SHOULD ALWAYS OBEY THE LAW

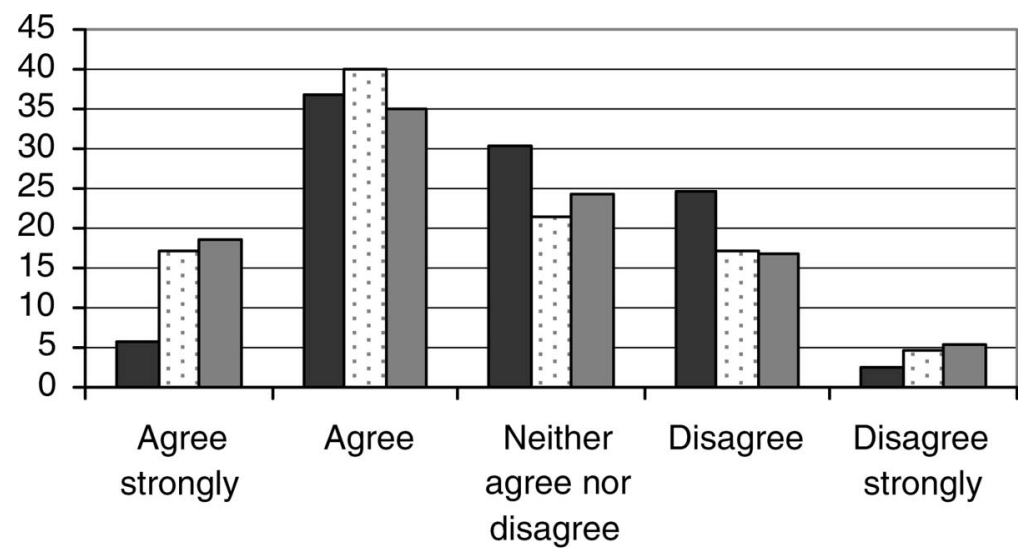

Flemish Region $\square$ Brussels Region $\quad \square$ Walloon Region 
FIGURE 4

ACCEPTANCE OF BRIBERY

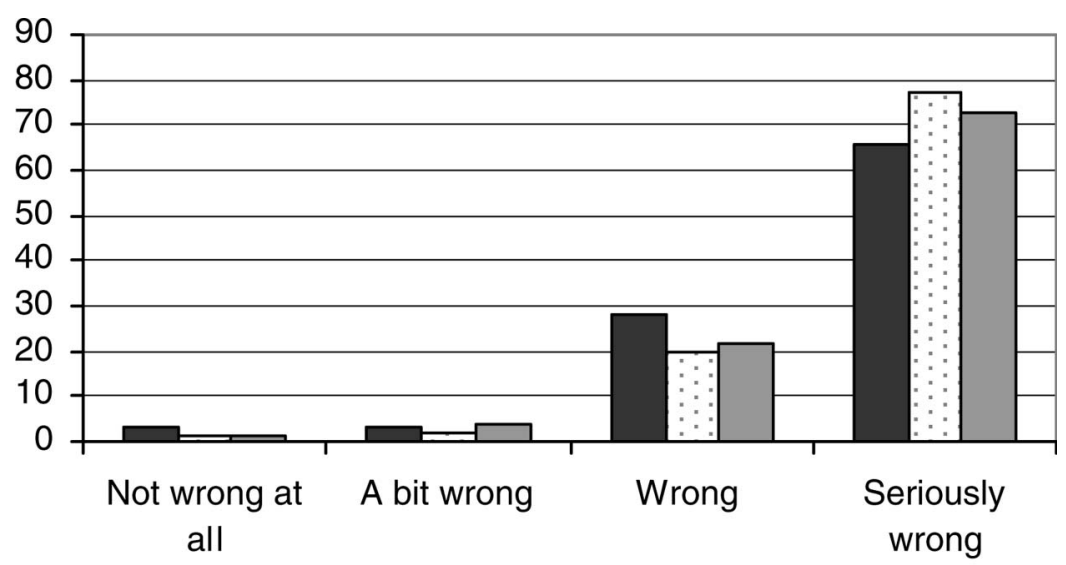

$\square$ Flemish Region $\quad \square$ Brussels Region $\square$ Walloon Region

Source: European Social Survey, round 2, 2005.

means missing good opportunities. The differences remain (albeit small), when controlling for a number of socio-demographics such as gender, education, age and self-reported level of urbanisation of domicile.

In conclusion, French-speaking Belgians seem to perceive more corruption than their Dutch-speaking counterparts, but tolerance towards corruption is lower among French-speakers. As for the latter, it is unclear whether the difference in tolerance is due to political culture or to a reaction against higher levels of perceived corruption. However, the small differences that do exist repeatedly falsify the proposition of a Flemish culture, which, because of its adherence to a northern political culture would be less tolerant towards corruption. This interesting observation is an obvious avenue for further research into the actual prevalence of corruption in the two parts of the country. In any case, bearing in mind the small differences between the two language communities, we can conclude that there is at first sight little indication of a clash of political cultures when it comes to corruption and that it may be hard to explain corruption by referring to regional culture.

\section{Explaining Corruption}

In line with the focus of this volume, we want to investigate whether Belgian-style federalism could go some way in explaining why the 1990s saw several cases of corruption. Yet, before we delve into federalism, we would list a few factors that are frequently mentioned as contributing or contextual factors to explaining corruption in Belgium. 
First and foremost, many authors refer to the complex of interrelated cultural factors that include fairly low trust in democratic institutions (e.g. Van de Walle 2007), relatively high tolerance towards breaking the law (e.g. Gibson and Caldeira 1996), and a culture of clientelistic relations between politicians and their voters for both individual favours and advantages for their constituency. Factors like these create a context that facilitates corrupt practices.

Second, in each of the Belgian regions, political parties and their presidents play a pivotal role. Until the end of the 1980s, the governing parties strongly controlled promotion in the civil service (De Winter 2003: 99), thus creating a possible avenue for dubious dependencies between politics and individual administrators. Political parties also had a strong impact on actual policy-making, particularly through the ministerial cabinets: the ministers' personal political advisors, often former party officials, seconded public servants or representatives of interest groups (see e.g. Pelgrims 2001). '[A]s they are central to departmental decision-making and are staffed by party loyalists, ministerial cabinets are evidently useful sites for organizing illicit activities' (De Winter 2003: 99).

Third, in an analysis of corruption in Belgium, Frognier (1986) considered consociationalist systems as more prone to corruption. Likewise, Lijphart, in his analysis of consociational systems, pointed out that 'it may be hypothesised that the greater clarity of responsibilities in majoritarian democracies inhibits corruption and that the consensus system's tendency to compromise and “deal-making” fosters corrupt practices' (Lijphart 1999: 289). Yet his empirical analysis of 36 countries did not reveal significant effects. Pujas and Rhodes (1999a) also argue that political competition does not function properly in a consociational system, because inter-party agreement is bought, and because there is no real control when you always cooperate with the same people. The ruling group will thus insulate itself from outside scrutiny, even if many parties are involved (Frognier 1986). The strong distinction between the ideological pillars in the Belgian consociational system, which have lived on after the federalisation of Belgium, and the close ties between a political party and a diversity of organisations within the same pillar (trade unions, public health bodies, professional organisations, and even market actors such as banks, architects or firms) lead to long-term alliances that are sensitive to political corruption, particularly when parties required extensive funding. For example, investigations into the role of Leo Delcroix in a number of high-profile scandals revealed that, as party secretary for the Flemish Christian Democrat party, he was at the centre of a network of friendly companies that also involved dubious forms of party financing.

Fourth, party fragmentation could in theory decrease opportunities for corruption, as complex coalition governments require more actors to be bribed and there is a higher risk of one of the parties blowing the whistle on illicit behaviour. Yet, although Belgium has one of the most fragmented 
party systems in Europe (see De Winter et al. this volume), for two reasons, it is very doubtful that this had a negative impact on corruption. For starters, party fragmentation coincided with spiralling costs in election campaigning, contributing to the Agusta-Dassault and a number of other party finance scandals (De Winter 2000). Furthermore, all the main parties seemed to share the fear of a 'chain of denunciation' (Frognier 1986) and thus 'signed' an 'implicit non-aggression pact' (De Winter 2003: 98) prohibiting the reporting of corrupt behaviour.

Some recent changes justify cautious optimism. A very important factor was a law in 1989 reducing the need for (illicit) party financing by strongly increasing government donations and capping the cost of election campaigns. Moreover, the 1990s saw a significant decrease in the politicisation of the judiciary and the administration through independent assessments of candidates. Meanwhile, administrations at different levels are experimenting with preventive measures of ethics management (Maesschalck 2005). A whistle-blowing act has been approved at the Flemish level (Maesschalck and Ornelis 2003) and is under consideration at the federal level. In the spring of 2006, a number of scandals were uncovered involving political and administrative behaviour in both Flanders and Wallonia in the past. Devastating as these revelations are, this behaviour is now public and appears to have stopped, which is a positive sign.

The reasons that are listed above fall beyond the scope of federalism. Yet would federalism, Belgian-style, have had an independent effect on the incidence of corruption? In the literature the empirical evidence of a link between federalism and corruption is shaky at best, and there are theoretical arguments to both support and reject such a relationship. For instance, using perception indicators, Treisman (2000: 401) found federal states to be more corrupt than unitary states. He also found that 'countries with more tiers of government tend to have higher perceived corruption' (Treisman 2002: 1), but the results were not straightforward. Federalism effects often disappear when other variables are included in the models (Bohara et al. 2004). This paragraph briefly discusses two mechanisms through which federalism might have an impact on corruption.

The first mechanism refers to proximity. Federalism is said to bring government closer to the people. This has at least two, contradictory, effects. Proximity increases accountability and control and might thus reduce corruption. Yet at the same time it stimulates more frequent and closer interaction and thus more opportunity for corruption (see e.g. Rose-Ackerman 2004). The relevance of this mechanism for Belgium will depend on how one interprets proximity. First, if one focuses on the quantitative dimension of the argument and on literal proximity in the sense of close interaction between political and bureaucratic officials and citizens, then the relevance seems very limited. Population size of the regions suggests it probably does not matter all that much whether we are dealing with a federalised or a unitary Belgian state. While Belgium has almost 10.5 million inhabitants (as 
of July 2005), the Flemish Region still has 6 million, and the Walloon 3.4 million. It is therefore unlikely that this federalism or regionalism would lead to greater proximity between citizens and politicians.

Furthermore, one could also interpret proximity in terms of values and political culture. In this sense, proximity might indeed have the two contradictory effects mentioned above. On the one hand, if principal (electorate) and agent (political and bureaucratic officials) share more values, it will be easier for the former to control the latter. On the other hand, shared values could make it easier for both parties in the interaction to actually engage in corrupt practices, because the availability of information on the other's motives and values lowers transaction costs and the risks of a corrupt encounter. Yet this argument only holds for Belgium if there are significant differences between the two main communities in political culture and particularly in attitudes towards corruption. Evidence for the latter is, as we discussed above, very weak.

The second mechanism refers to the increased competition that federalism allegedly creates. Public choice approaches attribute high levels of corruption to a lack of competition in the political arena, because competition is said to reduce politicians' discretionary power and 'diminish the value of bribing officials' (Bohara et al. 2004: 485). Thus, because of its scattered power structure, a federal structure requires that a large number of actors are bribed instead of just one, making it more difficult to influence decisions, but possibly leading to an increase in the total number of corrupt deeds (Treisman 2000: 407). Also, because there is a larger number of actors to extract bribes from the population or other actors (Treisman 2000: 433), political competition (both within and between parties) is likely to have the effect of keeping the level of bribes low (Shleifer and Vishny 1993: 610). Yet competition in a federal structure can also increase corruption: it makes constituents or clients less dependent on politicians or bureaucrats, because they can replace politicians or bring their case to another bureaucrat (Montinola and Jackman 2002: 147, 151). In a (federal) system with much political competition one only needs to bribe a segment of government to influence decisions.

In order to assess the relevance of these arguments about increased competition for the case of Belgian federalism, it is important to distinguish between those policies that are still entirely assigned to the national level (e.g. defence), policy areas which are shared by the regional and federal levels (e.g. employment) and policies which are entirely regional (e.g. education).

First, the arguments above are clearly relevant for those policy areas that are still entirely at the federal level, since federal decisions require the agreement of the two major language communities and the non-state-wide parties represented in the federal coalition government. However, these mechanisms were present at the outset of Belgium's federalisation process (see Deschouwer this volume) and therefore cannot be attributed to the latter as such. 
Second, Belgian federalism minimises the occurrence of shared, or concurrent, competencies (although different slices of a policy area, such as employment policy, are often attributed to different levels of government). 'Joint-decision' federations may increase the likelihood of corruption, since they make more officials, with less decisive power and with allegiances to different (levels of) government(s) responsible for policy implementation.

Third, the arguments presented above are not relevant for those policy areas in which the regions have gained full competence. In fact, one could argue that, compared with the situation prior to federalisation, the number of actors to be bribed has been reduced and their decision-making power increased. In the Belgian unitary state, the decision to initiate a large public infrastructure project required a complex balancing of regional interests (as is still the case for the federal policies described above). Yet 'waffle-iron' strategies became redundant in competencies that are entirely regional, as decision-makers gained the power and the budget to tailor policies to their own needs. The balancing act for these devolved competencies is thus much less complex and mainly depends on agreement within the governing coalition at the regional level, leading to fewer potentially corruptible decision-makers, but with more power. On the other hand, the federalisation of Belgium initially reduced competition at the regional level. Without directly elected regional parliaments until 1995 , federalisation contributed to strengthening the power of some pillar parties in the region in which they received most electoral support. For instance, in Wallonia, federalisation consolidated the hegemony of the Parti Socialiste and in Flanders it initially strengthened the role of the Christian Democrats. Traditionally, these are the strongest pillar parties which maintain strong links to a number of important auxiliary associations in health and education policy.

\section{The Impact of Federalism on Policy Failure in Belgium}

Federalism was introduced in Belgium to prevent the reoccurrence of a number of policy failures that emerged in the 1970s and 1980s. We will discuss these failures by means of a typology of three typical 'general failure types' that was developed by Boin and 't Hart (2000). They explain how these failure types (respectively crisis by ignorance, crisis by rigidity and crisis by failed intervention) act as endemic factors that contribute to a legitimacy gap between societal norms and performance and thus to policy failure. When applying this framework to Belgium, we can see how federalism was introduced as a means to avoid crises of all three general failure types.

First, a crisis by ignorance occurs when 'the dominant coalition in the sector fails to identify an externally perceived need for adaptation or reform' (Boin and 't Hart 2000). It is not difficult to find policy fields that have been neglected as a consequence of the political elite's occupation with the federalisation process in the 1970s and 1980s. During the Dutroux crisis in 
the mid-1990s, for example, many senior politicians admitted that problems in the police and justice sector had been largely ignored because the political elites were preoccupied with federalisation. For the same reason, administrative reform was long kept off the political agenda (Van de Walle et al. 2005; Brans et al. this volume).

A crisis by rigidity occurs 'when environmental changes are noted and understood, but the dominant coalition in the sector is unable to go beyond gradualist adaptation in its response' (Alink et al. 2001: 297). Despite its unitary status, pre-1970 Belgium was already marred with ideological, sociological and linguistic cleavages which regularly paralysed decisionmaking in the centre. Change was only possible through small incremental steps, leading to an equilibrium that was only infrequently punctuated by a pact. Although such pacts could pave the way for more drastic changes, these often arrived at the expense of enormous political efforts. An example of an area where this immobilism as a consequence of the complex structure occurred is the field of public finance and particularly the growing national debt. Although most actors realised the need for drastic cutbacks, the complex Belgian system did not allow for the kind of serious measures that were necessary, particularly in a context where problems were often solved by throwing money at them, for example in the 'waffle iron' tradition. Federalisation has reduced this complexity, creating more room for decisive action when needed (admittedly, the budgetary criteria imposed by the Maastricht Treaty also played an important role in enforcing budgetary discipline).

Finally, a crisis by failed intervention occurs when problems are addressed in the wrong way: 'applying the wrong solutions to the right problem or applying the right solutions to the wrong problem' (Boin and 't Hart 2000). Despite variations in political culture and socio-economic development, the unitary state did not create much room for policy differentiation. A good policy for one part of the country could take the form of a failed intervention for the other, for example, because the economic circumstances were entirely different. Federalisation enabled more focused and appropriate policies, at least for those policies in which the regions gained exclusive competence, reducing the chance of such types of failed intervention.

Yet, although federalisation may have reduced the chance of policy failures, federalism is not without risks either. First, a new version of a crisis of ignorance becomes possible. In those policy areas where competencies are clearly assigned to the regional level, there is a risk that the regions will develop their own idiosyncratic policies without knowing anything about policies in the other region, thus forgoing the opportunity for synergies or running the risk of contradictory policies. Other than at the federal level, there is little room for regular interaction between politicians representing the two language groups and the (linguistically) split media do not report extensively on the policies of the region that is associated with the other language group. 
Second, a new form of the crisis of rigidity also becomes possible. Having fought so long to acquire some competencies, regions may be very protective of them, rigidly following their own convictions even if it is obvious that an open-minded and flexible cooperation with the other region or the federal level would drastically increase policy effectiveness. Policy areas which are scattered between various levels or governments (such as environmental policy) are particularly prone to such risk, as the Belgian federal model cannot force the regions into binding cooperation agreements (see Swenden and Jans this volume). Furthermore, the Flemish government, in particular, may be prone to such behaviour, as it emphasises a rhetoric of 'wat we zelf doen doen we beter' ('what we do ourselves, we do better'). Systematic policy coordination only takes place in areas that are deeply affected by Europeanisation (see Beyers and Bursens this volume) and a widely shared attitude of 'Bundestreue' (federal comity) is still missing from the Belgian federal context.

\section{The Impact of Federalism on Scandal in Belgium}

Despite the media's focus on the facts behind a scandal, most authors do not see scandals as exceptional events, emanating from an objective fact or change. The 1990s featured a high incidence of scandals, not only in Belgium, but also elsewhere in the West. Most authors treat scandals as constructions, and point at the political opportunity structure as an explanation for their emergence: 'The appearance of a crisis is a political act, not a recognition of a fact or a rare situation' (Edelman 1988: 31).

The Belgian case seems to be no exception to this apparent broader trend of scandal-proneness. The early 1990s saw the emergence of a discourse on 'the confidence gap' between citizen and government. The phrase was coined by then opposition politician (and since 1999 federal Prime Minister) Guy Verhofstadt and assumed its full strength as a widely shared problem definition after the dramatic 1991 elections, in which the extreme rightwing party Vlaams Blok gained a spectacular increase in votes. Situations previously not generally defined as problematic suddenly became so. The air was filled with cries for a 'New Political Culture' that would eradicate power politics, and do away with much of the backroom decision-making.

Not all Belgian scandals in the 1990s can simply be reduced to changes in sensitivity or expectations, or to the political games that constructed them. The Agusta-Dassault corruption revelations followed the murder of socialist politician André Cools, the first national politician to be murdered in Belgium since communist leader Julien Lahaut in 1950. Rumour spread that the murder was related to a broad culture of fraud and corruption, and even mafia involvement. Despite the actual killers being imprisoned, no satisfactory motive has been found for the murder, but many corrupt practices have been uncovered during the investigation. This makes the Agusta case different from more 'mainstream' corruption cases. 
The abuse and killing of several young girls by a well-known and previously convicted sex offender, Marc Dutroux, hardly can be qualified as an average policy failure either. Against the background of the huge public outrage surrounding his arrest in 1996 and a widely held (but never proved) assumption that there were networks of powerful people who protected him, his short-lived accidental escape in April 1998 counts as one of the most absurd and shocking events in the history of Belgian criminal policy.

We now turn to federalism and its potential impact on three different stages in the development of a scandal: problem definition, scandal expansion and scandal coping or solution. With regard to problem definition, one should note that not all problems become scandals. Brändström and Kuipers (2003) identified the violation of crucial 'core values' as a prerequisite for incidents to develop into crises and to initiate a process of blaming. In Belgium, many problems are framed as resulting from deep-rooted differences in political culture, especially when it comes to issues of corruption or the management of public sector institutions. As such, the attempt to accentuate differences in political culture rather than federalism as an institutional variable underpins the making of several scandals. Above, we suggested that survey evidence for the existence of different regional attitudes towards corruption is weak. Yet the two language communities have deep-rooted stereotypes of each other, and frequently refer to these in the political discourse. Any event that confirms these stereotypes (e.g. 'a corrupt south') has a higher propensity to draw attention, and to develop into a scandal. In fact, recent years show that virtually all public policy issues can be framed in terms of a Flemish-Walloon juxtaposition, from administrative reform to tobacco advertising on sports events or the right of non-EU citizens to vote.

The rise of the extreme right in Flanders further contributed to this development. Since the arrival of the extreme right-wing Vlaams Blok/ Belang, cases of corruption are now widely used to generate political conflict. As a permanent opposition party (at least until now), the Vlaams Belang has no interest in maintaining the cosy backroom politics associated with consociationalism and thus has its hands free to frame any problematic occurrence as a scandal. Moreover, the party's extreme Flemish nationalist stance typically leads it to frame problems in terms of a clean Flanders that is deprived of its means by a corrupt and lazy south. Yet this rhetoric is not confined to extreme right parties. Regional identity has become a major element in the political game, and in the party-political game, often in a misguided attempt to win back votes from the extreme right.

With regard to an increase in scandal, it is noted that growing political competition has a great effect on this. However, as discussed above, federalism has not necessarily increased competition in the Belgian political system, certainly not until 2003, when federal elections were decoupled for the first time from regional elections. Even the strength of the extreme right 
in Flanders seems to have a double, contradictory effect on the level of scandal. On the one hand, they take a strong interest in expanding scandals, thus increasing pressure on the other parties to arrive at a "collective definition of the deviance as scandalous' (Sherman 1978: 64). On the other hand, by their quantitative strength (and as a consequence of the so-called cordon sanitaire, that is, the agreement of all the other parties not to enter in coalition with the Vlaams Belang), they force virtually all traditional parties together in coalition governments, thus effectively reducing the scope for competition between those parties.

Finally, as a young multi-ethnic federal state, debates about the future development of the federal system feature prominently in the political discourse, no matter what is the policy issue at hand. In the bipolar Belgian federation, Belgian political actors (particularly in Flanders) routinely and systematically present more federalism as the means to put emerging scandals to rest. This creates the risk that other, potentially more relevant, solutions are routinely overlooked.

\section{Conclusion: So what has Federalism to do with it?}

Our analysis suggests that Belgian federalism has a limited impact on the occurrence of corruption, policy failure and scandal. With regard to the former, we demonstrated differences in the acceptance of corruption between the two different language communities. Yet we could not present objective data to demonstrate that corruption is more frequent in Flanders than in Wallonia or vice versa. Other factors, such as the escalating needs for party finance in the 1980s and the consociational elitist political system which has been governed by a 'junta of party presidents', are likely to play a much larger role in explaining why Belgium often suffers from a corrupt image. However, federalism may have created some favourable conditions insofar as it reduced the complexity of political decision-making in the regions and increased electoral accountability. The decoupling of federal and regional elections increased opportunities to 'throw out the rascals'. On the other hand, in Flanders, the cordon sanitaire effectively reduced the levels of political competition by forcing all the other political parties (except for the Greens) into a grand coalition government.

The process of federalising Belgium absorbed much energy of the political leaders and put a brake on necessary reforms, for instance in the police and justice sectors, thereby increasing incidences of policy failure. Although still an ongoing process, the scope of competencies that are fit for decentralisation (other than social security and health) is much reduced, and the regions can expend more energy to tailor policy solutions to the political preferences of the regional electorates they represent. The low incidence of shared policy competencies in the Belgian federation further increases the scope for policy divergence and experimentation. On the other hand, infrequent interaction between regional governments which cross-cut the language divide and a 
desire of the Flemish to 'do things their way' constrain opportunities for policy transfer and learning. Frequently, more regional autonomy is seen as the best solution to policy failure and scandal, whereas alternative and potentially more cost-efficient solutions are often overlooked.

Our analysis suggests that many of the undesirable consequences that are commonly attributed to federalism might in fact be due to the coexistence of different cultures in Belgium, independent of federalism. Yet this claim remains only a hypothesis and is an obvious avenue for further research. Hard evidence of how the presence of different political cultures affects policy failures and scandal remains very limited, mainly because empirical research on inter-regional differences in civil and political culture is lacking. Most research comparing the regions focuses on differences in national/ regional or ethno-territorial identities (e.g. Billiet et al. 2003; De Winter et al. 1998), not on attitudes towards corruption or similar issues. Therefore, this would be an important avenue for further research.

Focusing on one explanatory variable, as we did with federalism, always carries a certain risk of bias, an exaggeration of the power of the variable to explain the dependent variables (corruption, policy failures and scandal) to the detriment of other potential explanatory variables. We have made efforts to avoid such biases, for example by referring to the impact of depillarisation and the rise of the extreme right, but an obvious avenue for further research consists of more thorough analyses that are systematically open for other explanations. The latter could include theoretically codified narrative accounts (see e.g. Maesschalck 2002 for such an analysis of the Dutroux scandal and its impact on police reform) or could rather focus on a limited number of explanatory factors, based on the study of a fairly large number of cases (see e.g. Bovens et al. 2001).

\section{Acknowledgements}

Steven Van de Walle would like to thank the Campbell Public Affairs Institute at the Maxwell School of Citizenship and Public Affairs (Syracuse University) for its hospitality when writing this article, and the National Fund for Scientific Research-Flanders (FWO Vlaanderen) for its financial support. Both authors would like to thank Wilfried Swenden and Sanneke Kuipers for their helpful comments.

\section{Note}

1. The data/tabulations utilised in this publication were made available by the ISPO and PIOPInteruniversity Centres for Political Opinion Research, sponsored by the Federal Services for Technical, Cultural and Scientific Affairs. The data were originally collected by Jaak Billiet, Marc Swyngedouw, Ann Carton and Roeland Beerten (ISPO) for the Flemish voters and André-Paul Frognier, Anne Marie Aish-Van Vaerenbergh, Serge Van Diest and Pierre Baudewyns (PIOP) for the French-speaking. Neither the original collectors of the data nor the Centre bears any responsibility for the analysis or interpretations presented here. 


\section{References}

Alink, Fleur, Arjen Boin and Paul 't Hart (2001). 'Institutional Crises and Reforms in Policy Sectors: The Case of Asylum Policy in Europe', Journal of European Public Policy, 8:2, 286-306.

Beerten, Roeland, Jaak Billiet, Ann Carton and Marc Swyngedouw (1997). 1995 General Election Study Flanders-Belgium: Codebook and Questionnaire. Leuven: ISPO Interuniversitair Steunpunt voor Politieke-Opinieonderzoek KULeuven.

Billiet, Jaak, Bart Maddens and Roeland Beerten (2003). 'National Identity and Attitude Toward Foreigners in a Multinational State: A Replication', Political Psychology, 24:2, $241-57$.

Bohara, Alok K., Neil J. Mitchell and Carl F. Mittendorff (2004). 'Compound Democracy and the Control of Corruption: A Cross-country Investigation', The Policy Studies Journal, 32:4, 481-99.

Boin, Arjen, and Paul 't Hart (2000). 'Institutional Crises and Reforms in Policy Sectors', in H. Wagenaar (ed.), Government Institutions: Effects, Changes and Normative Foundations. Boston: Kluwer Academic Publishers, 9-31.

Bovens, Marc, and Paul 't Hart (1996). Understanding Policy Fiascoes. New Brunswick, NJ and London: Transaction.

Bovens, Marc, Paul 't Hart and B. Guy Peters (2001). Success and Failure in Public Governance. A Comparative Analysis. Cheltenham: Edward Elgar.

Brändström, Annika, and Sanneke Kuipers (2003). 'From "Normal Incidents" to Political Crises: Understanding the Selective Politicization of Policy Failures', Government and Opposition, 38:3, 279-305.

Carton, Ann, Hendrik Van Geel and Sara De Pelsemaeker (2005). 'Basisdocumentatie SociaalCulturele Verschuivingen in Vlaanderen 2004'. Brussel: Ministerie van de Vlaamse Gemeenschap, Administratie Planning en Statistiek.

De Ruyver, Brice, Frederik Bullens, Tim Vander Beken and Nathalie Siron (1999). Anticorruptiestrategieën. De aanpak van corruptie en beïnvloeding bij de bestrijding van de hormonendelinquentie en de vleesfraude: een case study. Antwerpen: Maklu.

De Winter, Lieven (2000). 'Political Corruption in the Belgian Partitocracy: (Still) an Endemic Disease?' EUI Working Paper RSC No. 2000/31.

De Winter, Lieven (2003). 'Political Corruption in Belgium', in Martin J. Bull and James L. Newell (eds.), Corruption in Contemporary Politics. Houndmills: Palgrave Macmillan, 93105.

De Winter, Lieven, André-Paul Frognier and Jaak Billiet (1998). 'Y a-t-il encore des Belges? L'évolution des identités politiques des Wallons, des Bruxellois et des Flamands', in Marc Swyngedouw and Marco Martiniello (eds.), Où va la Belgique? Les Soubresauts d'une petite Démocratie européenne. Paris: L'Harmattan, 123-36.

Edelman, Murray (1988). Constructing the Political Spectacle. Chicago: University of Chicago Press.

Friedrich, Carl J. (1989). 'Corruption Concepts in Historical Perspective', in A.J. Heidenheimer, M. Johnston and V.T. LeVine (eds.), Political Corruption. A Handbook. New Brunswick, NJ: Transaction Publishers, 15-24.

Frognier, André-Paul (1986). 'Corruption and Consociational Democracy: First Thoughts on the Belgian Case', Corruption and Reform, 1, 143-8.

Gibson, James L., and Gregory A. Caldeira (1996). 'The Legal Cultures of Europe', Law and Society Review, 30:1, 55-87.

Inglehart, Ronald, Miguel Basanez, Jaime Díez-Medrano, Loek Halman and Ruud Luijkx (2005). Human Beliefs and Values: A Cross-Cultural Sourcebook on the 1999-2005 Values Surveys. México: Siglo XXI editores.

Jowell, R., and the Central Co-ordinating Team, European Social Survey 2004/2005 (2005). Technical Report. London: Centre for Comparative Social Surveys, City University. Data retrieved from the Norwegian Social Science Data Services (NSD). 
Lijphart, Arend (1999). Patterns of Democracy: Government Forms and Performance in Thirty-Six Countries. New Haven, CT: Yale University Press.

Maesschalck, Jeroen (2002). 'When do Scandals Have an Impact on Policy Making? A Case Study of the Police Reform Following the Dutroux Scandal in Belgium', International Public Management Journal, 5:2, 169-93.

Maesschalck, Jeroen (2005). Een ambtelijk integriteitsbeleid in de Vlaamse overheid. Leuven: Steunpunt Bestuurlijk Organisatie Vlaanderen.

Maesschalck, Jeroen, and Frank Ornelis (2003). 'Een interdisciplinaire analyse van de klokkenluidersproblematiek in de openbare sector', Tijdschrift Voor Bestuurswetenschappen En Publiek Recht, 58:8, 535-57.

Montinola, Gabriella R., and Robert W. Jackman (2002). 'Sources of Corruption: A CrossNational Study', British Journal of Political Science, 32, 147-70.

Pelgrims, Christophe (2001). Ministeriële kabinetsleden en hun loopbaan. Tussen mythe en realiteit. Brugge: Die Keure.

Pujas, Véronique, and Martin Rhodes (1999a). 'A Clash of Cultures? Corruption and the Ethics of Administration in Western Europe', Parliamentary Affairs, 52:4, 688-702.

Pujas, Véronique, and Martin Rhodes (1999b). 'Party Finance and Political Scandal in Italy, Spain and France', West European Politics, 22:3, 41-63.

Rose-Ackerman, Susan (2004). 'The Challenge of Poor Governance and Corruption', Copenhagen Consensus Challenge Paper.

Sherman, Lawrence W. (1978). Scandal and Reform: Controlling Police Corruption. Berkeley: University of California Press.

Shleifer, Andrei, and Robert W. Vishny (1993). 'Corruption', The Quarterly Journal of Economics, 108:3, 599-617.

Thompson, John B. (2000). Political Scandal: Power and Visibility in the Media Age. Cambridge: Polity Press.

Treisman, David (2000). 'The Causes of Corruption: A Cross-National Study', Journal of Public Economics, 76, 399-457.

Treisman, David (2002). 'Decentralization and the Quality of Government', unpublished paper, UCLA.

Van de Walle, Steven (2007). 'Perceptions of Corruption as Distrust? Cause and Effect in Attitudes Towards Government', in Leo Huberts, Carole Jurkiewicz and Jeroen Maesschalck (eds.), Ethics and Integrity of Governance: Perspectives across Frontiers. Cheltenham: Edward Elgar, forthcoming.

Van de Walle, Steven, Nick Thijs and Geert Bouckaert (2005). 'A Tale of Two Charters: Political Crisis, Political Realignment and Administrative Reform in Belgium', Public Management Review, 7:3, 367-90.

Van Kesteren, J.N., P. Mayhew and P. Nieuwbeerta (2000). Criminal Victimisation in Seventeen Industrialised Countries: Key-Findings from the 2000 International Crime Victims Survey. The Hague: Ministry of Justice, WODC.

Yante, Jean-Marie (2003). 'La Corruption dans l'Administration belge aux XIXe et XXe siècles', in Seppo Tiihonen (ed.), The History of Corruption in Central Government. Amsterdam: IOS Press, 65-82. 